IZA DP No. 7827

Do Business Visits Cause Productivity Growth?

Massimiliano Tani

Roselyne Joyeux

December 2013

Forschungsinstitut zur Zukunft der Arbeit Institute for the Study of Labor 


\title{
Do Business Visits Cause Productivity Growth?
}

\author{
Massimiliano Tani \\ UNSW Canberra \\ and IZA \\ Roselyne Joyeux \\ Macquarie University
}

\section{Discussion Paper No. 7827 \\ December 2013}

\author{
IZA \\ P.O. Box 7240 \\ 53072 Bonn \\ Germany \\ Phone: +49-228-3894-0 \\ Fax: +49-228-3894-180 \\ E-mail: iza@iza.org
}

Any opinions expressed here are those of the author(s) and not those of IZA. Research published in this series may include views on policy, but the institute itself takes no institutional policy positions. The IZA research network is committed to the IZA Guiding Principles of Research Integrity.

The Institute for the Study of Labor (IZA) in Bonn is a local and virtual international research center and a place of communication between science, politics and business. IZA is an independent nonprofit organization supported by Deutsche Post Foundation. The center is associated with the University of Bonn and offers a stimulating research environment through its international network, workshops and conferences, data service, project support, research visits and doctoral program. IZA engages in (i) original and internationally competitive research in all fields of labor economics, (ii) development of policy concepts, and (iii) dissemination of research results and concepts to the interested public.

IZA Discussion Papers often represent preliminary work and are circulated to encourage discussion. Citation of such a paper should account for its provisional character. A revised version may be available directly from the author. 
IZA Discussion Paper No. 7827

December 2013

\section{ABSTRACT}

\section{Do Business Visits Cause Productivity Growth?}

The production and diffusion of knowledge have increasingly been seen as potential causes of the observed international differences in total factor productivity and, in turn, as possible sources of economic growth. This paper presents the results of a causality study between business visits and multifactor productivity using a unique database that covers 30 sectors for 17 countries over the period 1998-2007. The results suggest that there is a causal link in some of the most innovative sectors from business visits to productivity. Business visits emerge as a fundamental channel for the spread of knowledge.

JEL Classification: F22, C32, C33

Keywords: international business travels, panel data, causality tests

Corresponding author:

Massimiliano Tani

Professor of Finance and Economics

UNSW Canberra

Northcott Dr, Campbell ACT 2612

Australia

E-mail: m.tani@adfa.edu.au 


\section{Introduction}

There is broad consensus among academics and policymakers that knowledge is a valuable source of competitive advantage for a firm, and of economic growth for a country, as it facilitates innovation and enhances productivity. Knowledge is a composite good. Some of its constituent elements are disembodied, like information and data. Their non-rivalry, codifiability and ease of communication provide a generic, undifferentiated advantage to its users. Other elements are embodied in individuals, like skills and experience, or intertwined in routines used by organisations (e.g. Arrow, 1969; Nelson and Winter, 1982; Romer, 1990). These give unique capabilities to firms and countries in solving problems, being innovative, and improving productivity.

Research has shown that the production of knowledge benefits from undertaking activities such as R\&D, manufacturing, and marketing (Cohen and Levinthal, 1991), as these foster problem-solving skills and learning, which, in turn, improve the ability to absorb and develop new knowledge. However, producing knowledge tends to be localised geographically (von Hippel, 1994), as it is bounded by history, culture, local habits and personality that can only develop over long periods of time through specific and almost accidental events. Reproducing the exact conditions that led a locale to become a knowledge hub is both costly and risky, if at all feasible. Nevertheless, firms and countries can access much of the knowledge produced elsewhere through a variety of channels, such as international students (e.g. Park, 2004), commodity trade and foreign direct investments (e.g. Keller, 2004), hiring of experts (e.g. Zellner, 2003; Franco \& Filson, 2006), and informal and social networks (e.g. Dahl \& Pedersen, 2004; Singh, 2005) 
The literature has also begun to investigate the role of international business visits in diffusing (e.g. Andersen and Dalgaard, 2011) and generating knowledge (e.g. Dowrick and Tani, 2011; Hovhannisyan and Keller, 2011). Business visitors are highly educated and occupy mostly professional, managerial and entrepreneurial jobs. Existing empirical work finds a positive correlation between business visits and productivity, or the generation of new patents.

However, to date and to our knowledge, there is no systematic evaluation of whether or not business visits cause higher productivity. Our paper aims to fill this gap. In particular we test the short- and long-term causality relationship between business visits and productivity by exploiting the concept of cointegration, which we apply on two unique sources of information: the large panel data on business visit expenditures collected the by the National Business Traveller Association (48 industries, 72 countries and 11 years), and the panel data on multifactor productivity collected by Eurostat (KLEMS - 31 industries, 25 countries, 28 years).

Two series are cointegrated if they are non-stationary in levels, stationary in first differences, and there exists a linear combination of the levels which is stationary (Engle and Granger, 1987). Such series move together through time, tracing a long-run path from which they are disturbed by temporary shocks but to which they continually readjust. The pushing forces, which bring the various processes back to equilibrium, are referred to as common trends - this is akin to a dog on a leash and his owner walking on the street: individually, each walk follows a random non-stationary process, but they cannot wander off from each other because of the 'relationship', the leash, between them. We comprehensively test whether business visits and multifactor series are cointegrated, and determine whether business visits cause productivity. 
We find a causal link running from business visits to multifactor productivity for most industries and countries. The relationship characterises some of the most innovative sectors, such as electrical and optical equipment, machinery, and telecommunication, whose $R \& D$ expenditures are also amongst the highest across all industries. These results suggest that business visits are a fundamental channel for generating and spreading knowledge. They also highlight the need to rethink the stance amongst (some) firms and countries of viewing business visits as mere expenditure with limited returns rather than investments in a strategic activity.

The rest of the paper is organised as follows: Section 2 briefly reviews the literature on visits and the principal hypotheses to be tested. Section 3 presents the data. Section 4 illustrates the methodology and Section 5 presents the results. Section 6 concludes.

\section{Literature}

The literature on business visits consists of a relatively small number of publications that can be broadly grouped in two streams. The first stream describes the main characteristics of business visits, their emergence and role within an organisation. Within this literature authors have highlighted the role of visits in the access and exchange of knowledge within and between firms, and the little substitutability between visits and other forms of distance communication like videoconferencing or emails. The reason underpinning the existence of business visits is that they allow participants to communicate face-to-face. This is essential in establishing trust between parties, which, in turn, is necessary to exchange complex, tacit or reserved information, or to establish the premises for alliances and subsequent communication and exchanges. These may occur by distance mode. Firms therefore invest in face-to-face communication to establish a network and find or evaluate information, or build alliances. 
Travelling also offers a signalling advantage as it is expensive and the host often acknowledges the extra effort made by the visitor taking the risk for establishing a partnership. This seems particularly relevant for inter-cultural relationships and especially in Asia. Compared with other forms of communication the net benefits of travelling may appear limited (e.g. Gertler, 2003), but this is not what emerges from case studies that repeatedly point to business travellers as a significantly over-skilled but under-utilised company resource (e.g. Welch and Welch and Worms, 2007). A recent large survey of travellers revealed that a common answer to the counterfactual of what would occur if their trip did not take place was a progressive 'detachment' (of traveller and employer) from the global technological and informational frontier that sets apart competing firms (Tani, 2011). The study estimates the conditional probability of exchanging knowledge through visits to be as high as $50 \%$ for conferences or trade fairs, even after controlling the self-selection of respondents participating to those events. The estimated unconditional probability is equally high at $40 \%$. Microeconomic analyses suggest therefore that knowledge diffusion is a potent motivator for undertaking business trips.

The second broad group of studies on business visits focuses on their effect on productivity or other performance measures. Gambardella, Mariani and Torrisi (2001) find that productivity across European regions is affected by openness as measured by the number of airplane passengers who disembarked in the region. Andersen and Dalgaard (2011) study 72 countries using data from the World Penn Tables 6.1 (real GDP, capital stock per worker and human capital stock per worker) and the World Development Indicators (international business arrivals and departures) for the period 1990-1996. They find an elasticity of 0.2 between the intensity of visits, measured as their proportion vis-àvis the home country's labour force, and aggregate multifactor productivity. Dowrick and Tani (2011) find a similar positive effect at the industry level based on 12 years of data 
for 12 sectors of the Australian economy. In particular, they find stronger effects for the home country when visitors are outgoing domestic residents rather than incoming foreign residents. Hovhannisyan and Keller (2011) find that a 10\% increase in business travel from the US leads to an increase in patenting in the host country by $0.3 \%$. Higher elasticities arise when the course location is a region with a high innovation rate, like California.

Additional evidence of the effect of business visits is found in a series of recent reports from the US Travel Association (Oxford Economics, 2009), the Air Transportation Action Group (ATAG, 2008), and the National Business Travel Association Foundation (NBTA, 2010). These reports have been commissioned by travel associations and lobby groups to fight the perception that expenditures in business visits are not strictly necessary, as proposed by corporation and politicians, during a time of economic austerity. The reports concur in finding that business visits are essential in enhancing the face-to-face communication of participants, which is a primary ingredient to establish successful business relationships. The reports highlight that a sudden stop to business visits, for example due to impediments or general fears of travelling as those which emerged after the attacks of September $11^{\text {th }} 2001$, can jeopardise firms' opportunities to develop new products and services, form collaboration, innovate, and remain successful. In particular, the National Business Travel Association (NBTA) has estimated that $10 \%$ increase in business visits is associated with a $20 \%$ increase in sales. The NBTA has also developed a unique database covering the business travel expenditures of 72 sectors for 48 countries over the period 1998-2008 using data from input-output tables, national accounts, and additional data sources to encourage analysis and discussion on the strategic relevance of business visits. 
Although both groups of studies highlight the role and effect of business visits, to date no analysis has been able to provide comprehensive testing of the relationship between business visits and multifactor productivity. Our study aims to fill this gap by testing the cointegration and causality links between business visits and productivity utilizing the NBTA database and another large dataset covering sectoral multifactor productivity for several countries.

\section{The Data}

Data on multifactor productivity come from the KLEMS database (http://www.euklems.net), supported by Eurostat, the European Union's statistical office. The KLEMS project standardises the methodology and estimation of multifactor productivity for a number of countries for the same period for which we have data on business visits' expenditures. A full description of the KLEMS database is in O'Mahony and Timmer (2009). The data contain industry-level measures of productivity for 25 European countries, Japan and the US for the period 1970 onwards. Other data sources, such as the OECD database, publish data only up to 2003 and contain a number of inconsistencies with regards to amounts for business expenditures within industries and across countries, which makes its use less attractive.

The data on business visits come from the NBTA. These data are constructed from inputoutput tables combined across 48 sectors for 72 countries during the period 1998-2008. The main sources of information were the national input/output accounts. When information was not available, HIS Global Insight generated data based on a proprietary estimation using matrices from countries with similar locations and industry mix. This enables the creation of input-output tables that were used in this analysis. A more comprehensive description of the data and the methodology applied to produce them is in NBTA (2010). Since NBTA data are built from national accounts, they do not express the 
flows of visitors in terms of number of visits but as expenditures in constant US\$ (and local currency). This has the advantage of enabling one to calculate the elasticity of a dollar spent on visits on productivity and other measures, making it comparable with estimates of elasticity for other knowledge activities such as R\&D expenditures. However, price measures have the disadvantage of averaging out the number of visits across those carrying them out and not have information on the individuals carrying out the visits.

Due to data availability constraints for multi factor productivity we only use the data for 30 industries in 17 countries from 1998 to 2007. The summary statistics are in Table 1. These show the average values of MFP, using 1995 as a base year, the expenditures on business visits per person in US\$ constant PPP dollars, business visits expenditures as a proportion of total output, and the average output per person in US\$ constant PPP dollars throughout the period. The data are ranked, in descending order, according to MFP.

Table 1 suggests that the countries of former Eastern Europe (Hungary, Czech Republic) and the newest members of the European Union (Austria, Sweden, Finland) were the ones with the fastest growth in MFP. This is perhaps related to positive economic shocks from integrating with larger economic blocks (the European Union). Slower, and intermediate, increases in average MFP occurred in the US (120.7) and the industrial economies of Western Europe (Germany, France, the UK). Productivity actually declined over the period in Italy and Spain, which, thanks to the rapid decline in interest rates following the introduction of the European common currency, experienced rapid increases in real wages.

With reference to business visit expenditures, Belgium emerges as the country with the highest expenditure on business visits per capita, followed by the Netherlands, Italy, Sweden, and Denmark. These are also the countries with the highest business visits 
expenditures as a proportion of output, possibly as a result of a significant export-oriented sector (e.g. Sweden, Italy), relatively small size or favourable tax treatment for foreign subsidiaries (Denmark, Netherlands), and the concentration of headquarters of international organisations (e.g. NATO, European Commission and European Council in Belgium). In some cases, business expenditures constitute a relevant proportion of output because of a country's geographic isolation (Australia) or proximity to the international markets they serve (Germany, France, UK, Canada). The countries with the lowest expenditures on business travel include nations with only medium levels of economic development (e.g. Hungary, Czech Republic), negative economic growth throughout the period (Japan), or an economy skewed towards non-tradable activities in tourism and construction (Spain).

The picture that emerges when data are grouped by country supports the existence of a negative relationship between average productivity and average business visit expenditures as a proportion of total output. The correlation is about -0.3 . It is however unlikely that industry sectors vary substantially across countries to justify an analysis by country groups, especially when technology (e.g. computers' hardware and software) and foreign direct investments or outsourcing linking productions and supply chains across national economies tend to even out differences that would be present if countries operated in complete autarky.

Table 2 summarises the data aggregated by industry during the period examined.

It reveals that the industries with the highest growth in productivity over the period are Electronic and Optical Equipment (264.6 on average versus 100 in 1995), followed by Post and Telecommunication (166.1), Transport Equipment (152.3), Rubber and Plastics (144.5) and Machinery nec (137.5). Growth in these industries has accompanied and favoured the entry of several large and low-income countries in the market-based world 
economy, contributing to its globalisation. Social services and sectors providing public goods (e.g. Education, Health, Community Services) tend to have constant MFP over time and hence gravitate towards the bottom of Table 2. The lowest average MFP growth was recorded in catering (Hotels and Restaurants) as well as Construction, leasing and rental activities, and utilities' supply, which typically use standard technologies to deliver their products and services. The correlation coefficient between the average expenditure of business visits as a proportion of output and average MFP is effectively nil.

Given those initial weak results, we test for cointegration between business visit expenditures and multifactor productivity using the full set of data available, and a comprehensive set of techniques.

\section{Methodology}

Given the features of the data, which constitute a panel with $\mathrm{N}=17$ countries $^{1}$ for 30 industries over $\mathrm{T}=10$ years from 1998 to 2007, we apply panel techniques to test for causality between the series of log of visit expenditures per industry employee (BTEXP) and the log of multi factor productivity $(M F P)$. The use of a panel data methodology in this context improves the power of non-causality tests applied to time series. We apply both long-run and short-run causality tests which are based in both instances on heterogeneous dynamic models. It is therefore possible to test the relations between visit expenditures and multi factor productivity without considering the same dynamic model for all the countries in the sample.

Before we conduct causality tests between the variables of interest, it is necessary to perform unit root and cointegration tests to test the stationarity and long-run relations of the two variables.

\footnotetext{
${ }^{1}$ Australia, Austria, Belgium, Czech, Denmark, Finland, France, Germany, Hungary, Ireland, Italy, Japan, Netherland, Spain, Sweden, UK, and USA.
} 
We use two tests for short-run causality. The first one follows the approach presented in Dumitrescu and Hurlin (2012) and Hurlin and Venet (2008). Basically they test for causality using stationary VAR models with fixed coefficients. The null hypothesis is the Homogeneous Non Causality (HNC) hypothesis under which there are no causal relations for all the units of the panel. The alternative is the Heterogeneous Non Causality (HENC) hypothesis. The VAR models for the different countries may have distinct lag structures and unconstrained coefficients under both the null and the alternative. The null is no causality in any country against the alternative that causality exists for a non-negligible proportion of the countries. The second test consists in estimating the following equations individually for each country allowing for heterogeneity of the coefficients and the variances:

$$
\Delta M F P_{i t}=\alpha_{i}+\sum_{k=1}^{p} \gamma_{i}^{(k)} \Delta M F P_{i t-k}+\sum_{k=1}^{p} \beta_{i}^{(k)} \Delta B T E X P_{i t-k}+\varepsilon_{i t}
$$

and testing for the hypothesis that the lagged changes in BTEXP can be excluded jointly from the equations for all the countries. The same test can be performed with the change in business visits as the dependent variable.

We use tests developed by Canning and Pedroni (2008) to test for long-run causality allowing for panel heterogeneity. The null is no causality in any country and the alternative is that causality exists for a non-negligible proportion of the countries. The alternative differs from most other panel tests which require long-run causality being present in at least one of the countries.

Finally, we estimate the long-run elasticities of multifactor productivity with respect to business travel expenditures using the group-mean Panel Dynamic Ordinary Least Squares (Panel DOLS) proposed by Pedroni (2001). 


\subsection{Panel Unit Root Tests}

We consider two panel unit root tests: the Im, Pesaran and Shin (2003) (IPS) and Pesaran (2007) tests. The first test assumes cross-sectional independence, whereas the second one does not. Baltagi et al. (2007) show that panel unit root tests suffer from size distortion in the presence of cross-section dependence. Pesaran (2007) should therefore be a more reliable test than IPS.

The IPS test is based on computing the adjusted average of the Augmented Dickey Fuller (ADF) individual unit root test statistics. The null is unit root for every country against the alternative of stationarity for a non-negligible proportion of the countries.

The Pesaran (2007) test is based on the assumption that cross section dependence is due to a single common factor. The standard ADF regressions can be augmented with the cross-section averages of lagged levels and first-differences of the individual series as proxies for the factor. Two tests are developed. One test is constructed from the simple averages of the individual IPS ADF statistics, this is the cross-sectionally augmented IPS test (CIPS). The other is a truncated version of the CIPS test (CIPS*) to avoid undue influences of extreme outcomes when $T$ is small.

\subsection{Panel Cointegration Tests}

Pedroni $(1997,1999,2004)$ develops tests for the null of no cointegration which are robust to endogeneity of the explanatory variables and allow for both heterogeneous cointegrating vectors and short-run dynamics.

Pedroni (1999) uses the following model:

$$
M F P_{i t}=\delta_{0 i}+\delta_{1 i} t+\delta_{2 i} B T E X P_{i t}+u_{i t}
$$

where the regressors may be endogenous. 
Common time dummies can be included in (2) to handle cross section dependence.

Assuming $\mathrm{MFP}_{t}$ and $B T E X P_{t}$ have unit roots, i.e. are I(1) processes, they are cointegrated if the error term in (2) is stationary. Pedroni $(1999,2004)$ proposes seven tests to test the null hypothesis of no cointegration for all countries. Wagner and Housklova (2010) examine the small sample properties of panel cointegration tests. They find that the tests applying the ADF principle perform best, whereas all other tests are severely undersized and have low power when $T \leq 25$. Therefore we only present the group-mean ADF test. We reject the null with the group-mean ADF test, if we have cointegration for a significant fraction of the cross-section units.

\subsection{Causality Tests}

Short-run causality tests

If $M F P_{t}$ and $B T E X P_{t}$ are found to be I(1) processes to test for short-run causality we assume that the data generating process is a VAR model in first differences. The VAR equation for $\triangle M F P$ is:

$$
\Delta M F P_{i t}=\alpha_{i}+\sum_{k=1}^{p} \gamma_{i}^{(k)} \Delta M F P_{i t-k}+\sum_{k=1}^{p} \beta_{i}^{(k)} \Delta B T E X P_{i t-k}+\varepsilon_{i t}
$$

Starting values for $\triangle M F P_{i t}$ and $\triangle B T E X P_{i t}$ are assumed to be observed. The individual effects $\alpha_{i}$ are assumed to be fixed. We allow for heterogeneity of the dynamic VAR model since $\gamma_{i}^{(k)}$ and $\beta_{i}^{(k)}$ may differ across cross-section units. The error terms $\varepsilon_{i t}$ are assumed to be i.i.d. $\left(0, \sigma_{i}^{2}\right)$ and independently distributed across units.

We first use the test proposed by Dumitrescu and Hurlin (2012). Under the null we have homogeneous non causality (HNC), i.e. 


$$
H_{0}: \beta_{i}=0 \quad \forall i=1, \ldots, N
$$

where $\beta_{i}=\left(\beta_{i}^{(1)}, \ldots, \beta_{i}^{(p)}\right)^{\prime}$. Under the alternative hypothesis we have

$$
\begin{aligned}
H_{1}: \beta_{i}=0 & \forall i=1, \ldots, N_{1} \\
\beta_{i} \neq 0 & \forall i=N_{1}+1, N_{1}+2, \ldots, N
\end{aligned}
$$

where $N_{l}$ is unknown and $N_{l}<N$. This means that there can be non-causality for some of the countries under the alternative (the causal relationships may be heterogeneous across countries). ${ }^{2}$

The panel test statistic is calculated as the average of individual Wald statistics defined to test the Granger non causality hypothesis for each country. Under the assumptions above the panel statistic sequentially converges under the HNC hypothesis to a normal distribution, when $T$ tends to infinity first and then $N$ tends to infinity. Using a standardized statistic, $Z_{N, T}^{H N C}$, the homogeneous non-causality (HNC) hypothesis is rejected if $Z_{N, T}^{H N C}$ is larger in absolute value than the corresponding normal critical value for a given level of significance.

Dumitrescu and Hurlin (2012) show that the small sample power properties of their test exceed that of time series Granger causality tests even for small values of $T$ (e.g. around $10)$.

Our second test consists in estimating for each country equation (3). We use a likelihood ratio test to test the null hypothesis of $\mathrm{HNC}, H_{0}: \beta_{i}=0 \quad \forall i=1, \ldots, N$. The likelihood ratio statistic is just the sum of the individual ratio statistics and is distributed as a $\chi^{2}$ with $N p$ degrees of freedom.

\footnotetext{
${ }^{2}$ Holtz-Eakin, Newey and Rosen (1988) proposed a panel causality test of HNC against the alternative of homogeneous causality. The Dumitrescu and Hurlin (2012) test is therefore more general.
} 
Under the alternative hypothesis, there is causality from $\triangle B T E X P$ to $\triangle M F P$ for at least one country. It is expected that this test would reject the null more often since it does not require rejection for a "significant" proportion of countries as is the case with the Dumitrescu and Hurlin (2012) test.

\section{Long-run causality tests}

For cointegrated I(1) variables we use the approach proposed by Canning and Pedroni (2008) to test for long-run causality. If $M F P_{t}$ and $B T E X P_{t}$ are cointegrated, then there exists an error correction model (ECM) relating those two series. We estimate the error correction model for each country in two steps. In the first step we estimate the long-run cointegrating relationship between $M F P_{t}$ and $B T E X P_{t}$ using fully modified ordinary least squares (FMOLS) and obtain the error correction term, $\hat{e}_{i t}$. In the second step, we estimate the error correction model:

$$
\Delta M F P_{i t}=c_{1 i}+\lambda_{1 i} \hat{e}_{i t-1}+\sum_{j=1}^{p} \gamma_{1 i j} \Delta\left(M F P_{i t-j}\right)+\sum_{j=1}^{p} \gamma_{2 i j} \Delta B T E X P_{i t-j}+\eta_{i t}
$$

for each country $i$, where $\eta_{i t}$ is the disturbance term. The asymptotic properties of the estimators in (6) are not affected by the fact that we use the estimated error correction term due to the superconsistency of the estimator for the cointegrating relationship. To test the null hypothesis that there is no long-run effect of $\triangle B T E X P$ on $\triangle M F P$ we use a group mean test computed as: $\bar{t}_{\lambda_{1}}=\frac{\sum_{i=1}^{N} t_{\lambda_{1 i}}}{N}$ where $t_{\lambda_{i i}}$ is the individual country $t$ test on $\lambda_{\lambda_{i}}$. The group mean test statistic has an asymptotic normal distribution under the null of no long-run causal relationship. There is, however, a drawback with the group mean test. For example, if the $t$-ratios are negative and significant for some of the countries and positive and significant for some others, it is possible that the average $t$ is insignificant. Therefore 
we complement the group mean test with the lambda-Pearson test. The lambda-Pearson statistic is defined as the accumulated marginal significance associated with the $t$-tests. This is equal to $P_{\lambda_{1}}=-2 \sum_{i=1}^{N} \ln p_{\lambda_{1 i}}$ where $\ln p_{\lambda_{1 i}}$ is the $\log$ of the $p$-value of the $i$ th country $t$ test. The $P_{\lambda_{1}}$ statistic is distributed as a $\chi^{2}$ with $2 N$ degrees of freedom under the null of no long-run causal relationship for the panel.

\section{Results}

The results are presented according to the sequence of the tests performed. Namely we first present the results of the tests about stationarity (or unit roots), followed by the cointegration tests. We then discuss short- and long-run causality tests. Finally, we discuss the estimated long-run elasticities of multifactor productivity with respect to business travel expenditures using the Panel DOLS estimates

\subsection{Unit Root Tests}

The panel unit root tests for the 30 industries are displayed in Tables 3 and 4 in the Appendix. In particular Table 3 reports the results for each industry and on estimations carried out on variables expressed in levels and first differences. Table 4 presents a summary of the conclusions that may be drawn on the basis of the various results displayed in Table 3. The panel unit root test results provide strong evidence that both BTEXP and MFP are I(1) for most of the industries. The only exception is "domestic services" for which BTEXP is found to be $\mathrm{I}(0)$ with both unit root tests. Overall, the results of unit root tests support our approach, namely applying cointegrating techniques to study the possible relationship between two non-stationary time series. 


\subsection{Panel Cointegration Tests}

The Pedroni $(1999,2004)$ panel cointegration test statistics are displayed in Table 5. The tests are performed with the dependent variable chosen to be $M F P$ and the independent variable to be $B T E X P$. We find cointegration between $B T E X P$ and $M F P$ for all industries except transport equipment. These results suggest beyond doubt that there is a long-run relationship between business visit expenditures and multifactor productivity. In other words, these two series are not moving independently of each other but are connected by an underlying factor (the leash in the dog/owner example of the Introduction). One such possible factor is the additional knowledge that is accessed or created through interactions carried out by business visits. As highlighted elsewhere, business visits mostly occur to exchange knowledge rather than for marketing purposes. The counterfactual most often mentioned by managers in microeconomic surveys of travellers is that not travelling would jeopardise their information about what occurs either in another part of the organisation or in the marketplace, similarly to moving away from the knowledge frontier of their respective industries. In such respect, business visits are a necessity to remain competitive and maintain the presence/relevance of an organisation in the market vis-àvis its competitors.

Having established that there is a cointegrating relationship between business visits and multifactor productivity, we test the causality of such relationship. A causality running from business expenditures to productivity would support our prior that business visits are knowledge producing activities per se, with the essential feature of improving productivity. They would emerge as a strategic activity for firms and countries seeking a competitive edge on knowledge-related capabilities. 


\subsection{Panel Short-run Causality Tests}

Dumitrescu and Hurlin (2012) test

We first present the results on short-run causality in Tables 6 and 7. In particular, Table 6 reports the $p$-values of tests performed on first differences with causality running from BTEXP to MFP. Table 7 presents a summary table of the conclusions one may draw from all the tests presented in Table 6 . The significance of short-run causality test is to illustrate the degree of dependence between the two time series during the transition towards a steady state (or long-run equilibrium). The results in Tables 6 and 7 show that, at the $10 \%$ significance level, for 14 industries out of 30 we reject non-causality from BTEXP to MFP when applying the test on the variables in levels (electrical equipment, transport equipment, rubber, other non metallic minerals, machinery, manufacturing, mining, pulp, wholesale trade, hotels, post and telecommunications, electricity and gas, transport). When applying the test to the variables in first differences we reject the null only for two industries (transport and equipment, pulp).

\section{Joint Test on the countries}

The joint test is applied on the first differences of BTEXP and MFP. We find that BTEXP causes MFP for 24 industries out of 30 (Tables 6 and 7). The industries for which we reject non-causality include industries with high value added and intensive in R\&D and innovation, like Electrical and optical equipment, transport equipment, manufacturing nec (e.g. software), energy production and metal-related industries.

In contrast, we cannot reject non-causality for Chemicals, Machinery, Electricity, gas and water supply, Health and social work, Financial intermediation, and domestic services. Many of these sectors supply public goods or public goods-type products and services, or 
are involved in the distribution of services (like utilities and financial intermediation) where competition, or expansion, is constrained and, with it, the scope to further improve productivity.

\subsection{Panel Long-run Causality Tests}

The results for the long-run causality tests are presented in Table 8. Using the group mean $t$ test we reject non-causation from $B T E X P$ to $M F P$ in the long-run for 15 out of 30 industries. However, using an alternative test of panel data long-run causality (the lambda-Pearson test), we find long-run causality for all industries. We interpret the results as indicative of an underlying relationship running from BTEXP to MFP but where the clear-cut evidence is hard to establish in presence of a still limited amount of data. The 10 years of data available are a bare minimum to run the tests discussed above, which typically include a number of lags beyond the one or two that we are able to include without running into robustness problems.

The results obtained, however, confirm the presence of a causal relationship whereby $M F P$ depends on BTEXP, and where therefore a drop in BTEXP may cause $M P F$ in both the short- and long-run to slow down or drop.

\section{$5.5 \quad$ Long-run Elasticities}

The estimated Panel DOLS long-run elasticities of multifactor productivity with respect to business travel expenditures are presented in Table 9. The estimates tend to be in the range 0.01 for industries related to government and the provision of public goods (e.g. public administration, education, health) to about 0.2 for many manufacturing industries. Higher estimates arise in the case of electrical and optical equipment (0.61), chemicals (0.54), finance (0.49), primary industries $(0.45)$, post and telecommunication services (0.39), and machinery (0.31). These estimates are in line with those found by the existing literature (e.g. Andersen and Dalgaard, 2011; Hovhannisyan and Keller, 2011; Dowrick 
and Tani, 2011), supporting the presence of a small but not insignificant link between visits and aggregate productivity, especially in the case of industries with a relatively high incidence of $R \& D$ expenditures.

\section{Implications for Policy and Conclusions}

The test results are perhaps the clearest indication obtained to date that business visits have a direct effect on productivity across economies and, most importantly, across the most strategic industries for developed economies. Namely, the industries which account for the largest share of R\&D expenditures and which employ large numbers of scientists and engineers in addition to other highly qualified people. This finding is of direct relevance for firms and countries that are questioning the benefits of face-to-face interactions vis-à-vis their immediate costs. For the firm, our results show that decisions about how much to interact through visits, and who should do so, ought to be included in the strategies employed to acquire knowledge and strengthen its capabilities. Planning should accompany budgeting choices about which events to attend and adequate metrics should be put in place to measure with some precision the returns associated with them. Without planning and measurement organisations may leave travel budgeting decisions to discretion based on current financial circumstances, with no attention to the fact that travelling can be a source of gaining knowledge, innovation, and a competitive edge over rival organisations. As a result, at times of economic difficulties, the travel budget runs the risk of being chopped as its outcome is both not well understood and not linked to the strengthening of an organisation's core competences. Our results indicate that these visits are not necessarily 'perks' and that generic cuts in the travelling budget may cost a firm more than a visit's financial expenses. At an aggregate level, our results show that a 
country can benefit from a more interconnected (face-to-face) workforce through productivity gains.

From a policy viewpoint the tests discussed in this paper support investing in infrastructures to facilitate face-to-face interactions and events where knowledge exchanges are possible, like conferences and trade fairs. Interacting can be a source of knowledge-production and higher productivity rather than a one-off expenditure with no externality and consequences.

This paper is part of a research project funded by ARC grant no. LP 0561107 and the Department of Immigration and Citizenship (DIAC). We are grateful to the National Business Travel Association for granting us access to the data. 


\section{References}

Air Transportation Action Group (ATAG) (2008). The economic and social benefits of air transport. Geneva: ATAG. http://atag.org/our-publications/archivedpublications.html accessed 27 March 2013

Andersen, T. B., \& Dalgaard, C. J. (2011). Flows of people, flows of ideas, and the inequality of nations. Journal of Economic Growth, 16(1): 1-32.

Arrow, K. J. (1969). The organization of economic activity: issues pertinent to the choice of market versus nonmarket allocation. The analysis and evaluation of public expenditure: the PPB system, 1: 59-73.

Baltagi, BH., Bresson, G., Pirotte, A. (2007). Panel unit roots and spatial dependence, Journal of Applied Econometrics, 22: 339-60.

Canning, D., \& Pedroni, P. (2008). Infrastructure, long-run economic growth and causality tests for cointegrated panels, Manchester School, 76: 504-27.

Cohen, W. M., \& Levinthal, D. A. (1990). Absorptive capacity: a new perspective on learning and innovation. Administrative Science Quarterly, 128-152.

Dahl, M. S., \& Pedersen, С. Ø. (2004). Knowledge flows through informal contacts in industrial clusters: myth or reality?. Research Policy, 33(10): 1673-1686.

Dowrick, S., \& Tani, M. (2011). International business visits and the technology frontier. Economics Letters, 110(3): 209-212.

Dumitrescu, E.I., \& Hurlin, C. (2012). Testing for Granger non-causality in heterogeneous panels. Economic Modelling, 29:1450-60.

Engle, RF., \& Granger, CWJ. (2007). Co-integration and Error Correction: Representation, Estimation, and Testing. Econometrica, 55:251-76.

Franco, A. M., \& Filson, D. (2006). Spin-outs: knowledge diffusion through employee mobility. The RAND Journal of Economics, 37(4): 841-860.

Gambardella, A., Mariani, M., \& Torrisi, S. (2009). How 'provincial'is your region? Openness and regional performance in Europe. Regional Studies, 43(7): 935-947.

Gertler, M. S. (2003). Tacit knowledge and the economic geography of context, or the undefinable tacitness of being (there). Journal of Economic Geography, 3(1): 7599.

Holtz-Eakin, D., Newey, W., \& Rosen, HS. (1988). Estimating vector autoregressions with panel data. Econometrica, 56:1371-95.

Hovhannisyan, N., \& Keller, W. (2011). International Business Travel: An Engine of Innovation? (No. w17100). National Bureau of Economic Research. 
Hurlin C., \& Venet B. (2008). Financial development and growth: a re-examination using a panel granger causality test. Working Papers halshs-00319995_v1, HAL.

Keller, W. (2004). International Technology Diffusion. Journal of Economic Literature, 42(3): 752-782.

Im, KS., Pesaran MH., \& Shin, Y. (2003). Testing for Unit Roots in Heterogeneous Panels. Journal of Econometrics,115: 53-74.

National Business Travel Association Foundation (2010). Business Travel Market Matrix. A global analysis of business travel activity.

Nelson, R. R., \& Winter, S. G. (1982). An evolutionary theory of economic change. Belknap press.

O'Mahony, M., \& Timmer, M. P. (2009). Output, input and productivity measures at the industry level: The EU KLEMS database. The Economic Journal, 119(538): F374-F403.

Oxford Economics (2009). The return on investment of business travel. http://www.oxfordeconomics.com/Media/Default/Industry\%20verticals/Tourism/ US\%20Travel\%20Association\%20ROI\%20on\%20US\%20Business\%20Travel.pdf. Accessed 30 March 2013.

Park, J. (2004). International student flows and R\&D spillovers. Economics Letters, 82(3): 315-320.

Pedroni, P. (1997). Cross Sectional Dependence in Cointegration Tests of Purchasing Power Parity in Panels. Working Paper in Economics, Indiana University.

Pedroni, P. (1999). Critical values for cointegration tests in heterogeneous panels with multiple regressors. Oxford Bulletin of Economics and Statistics, 61:727-731.

Pedroni, P. (2001). Purchasing power parity tests in cointegrated panels. Review of Economics and Statistics, 83:727-31.

Pedroni, P. (2004). Panel cointegration, asymptotic and finite sample properties of pooled time series tests with an application to the PPP hypothesis. Econometric Theory, 20: 597-625.

Pesaran, H. (2007). A simple panel unit root test in the presence of cross-section dependence. Journal of Applied Econometrics, 22: 265-312.

Romer, P. M. (1990). Endogenous Technological Change. Journal of Political Economics, 98: S71-S102.

Singh, J. (2005). Collaborative networks as determinants of knowledge diffusion patterns. Management Science, 51(5): 756-770. 
Tani, M. (2011). Business visits and the quest for external knowledge. IZA Discussion Papers series, No. 5436.

Von Hippel, E. (1994). 'Sticky information' and the locus of problem solving: implications for innovation. Management Science, 40(4): 429-439.

Welch, D. E., Welch, L. S., \& Worm, V. (2007). The international business traveller: a neglected but strategic human resource. International Journal of Human Resource Management, 18(2): 173-183.

Zellner, C. (2003). The economic effects of basic research: evidence for embodied knowledge transfer via scientists' migration. Research Policy, 32(10): 1881-1895. 
Table 1 Summary Statistics by Country, Ranked by MFP

\begin{tabular}{lcccc}
\hline Country & $\begin{array}{c}\text { MFP } \\
\mathbf{1 9 9 5}=\mathbf{1 0 0}\end{array}$ & $\begin{array}{c}\text { BT exp/empl } \\
\text { US\$/person }\end{array}$ & $\begin{array}{c}\text { BT exp/output } \\
\text { \% }\end{array}$ & $\begin{array}{c}\text { Output/empl } \\
\text { US\$/person }\end{array}$ \\
\hline Hungary & 152.3 & 0.875 & 0.44 & 211.3 \\
Sweden & 151.7 & 5.371 & 1.30 & 422.2 \\
Austria & 139.3 & 5.096 & 1.27 & 368.7 \\
Czech Republic & 133.3 & 1.138 & 0.68 & 156.1 \\
Finland & 131.7 & 3.497 & 0.88 & 377.9 \\
France & 124.3 & 2.947 & 0.75 & 376.6 \\
US & 120.7 & 5.292 & 1.15 & 463.5 \\
Germany & 118.5 & 2.233 & 0.59 & 378.8 \\
Netherlands & 117.2 & 7.891 & 1.30 & 670.1 \\
Ireland & 117.1 & 3.834 & 1.23 & 302.2 \\
UK & 114.0 & 3.821 & 1.00 & 384.5 \\
Canada & 111.4 & 2.201 & 0.91 & 250.5 \\
Belgium & 105.5 & 10.089 & 1.36 & 814.7 \\
Japan & 105.0 & 3.419 & 0.74 & 439.9 \\
Australia & 104.0 & 3.698 & 1.28 & 305.5 \\
Denmark & 100.1 & 5.484 & 1.12 & 540.9 \\
Italy & 98.4 & 5.768 & 1.32 & 392.9 \\
Spain & 95.4 & 2.867 & 0.74 & 380.9 \\
\hline Average & 120.8 & 4.358 & 1.00 & 408.4 \\
Correlation with MFP & 1 & -0.2779 & -0.2193 & -0.3496 \\
\hline
\end{tabular}

Table 2 - Summary Statistics by Industry

\begin{tabular}{|c|c|c|c|c|}
\hline Industry & $\begin{array}{c}\text { MFP } \\
1995=100\end{array}$ & $\begin{array}{l}\text { BT exp/empl } \\
\text { US\$/person }\end{array}$ & $\begin{array}{c}\text { BT exp/output } \\
\%\end{array}$ & $\begin{array}{c}\text { Output/empl } \\
\text { US\$/person }\end{array}$ \\
\hline ELECTRICAL AND OPTICAL EQUIP & 264.6 & 2.545 & 0.77 & 318.9 \\
\hline POST AND TELECOMM. & 166.1 & 3.411 & 1.30 & 244.2 \\
\hline TRANSPORT EQUIPMENT & 152.3 & 1.697 & 0.44 & 382.6 \\
\hline Rubber and plastics & 144.5 & 5.635 & 2.27 & 233.6 \\
\hline MACHINERY, NEC & 137.5 & 0.941 & 0.35 & 252.5 \\
\hline AGRIC., HUNT., FOREST AND FISH & 133.0 & 0.883 & 0.83 & 101.7 \\
\hline OTHER NON-METALLIC MINERAL & 128.4 & 5.239 & 2.07 & 240.2 \\
\hline Wholesale trade and commission trade & 127.4 & 2.118 & 1.07 & 187.2 \\
\hline PULP, PAPER, PRINT AND PUBLIC & 126.7 & 4.353 & 1.40 & 289.9 \\
\hline TEXTILES, LEAT. AND FOOTWEAR & 126.2 & 1.838 & 1.01 & 163.8 \\
\hline FINANCIAL INTERMEDIATION & 124.9 & 2.105 & 0.72 & 272.7 \\
\hline Retail trade, except of motor vehicles & 123.4 & 0.219 & 0.21 & 98.2 \\
\hline Chemicals and chemical products & 122.7 & 2.278 & 0.35 & 588.1 \\
\hline WOOD AND OF WOOD AND CORK & 122.5 & 3.186 & 1.55 & 189.6 \\
\hline BASIC AND FABRICATED METALS & 117.8 & 1.893 & 0.64 & 280.4 \\
\hline MANUF. NEC; RECYCLING & 117.8 & 1.734 & 0.92 & 173.9 \\
\hline Coke, refined petroleum and nuclear fuel & 111.5 & 34.71 & 0.78 & 4109.8 \\
\hline ELECT., GAS AND WATER SUPPLY & 110.6 & 25.605 & 3.46 & 682.6 \\
\hline TRANSPORT AND STORAGE & 107.3 & 2.458 & 1.11 & 205.7 \\
\hline FOOD, BEVER. AND TOBACCO & 106.3 & 7.45 & 2.02 & 333.8 \\
\hline DOMESTIC SERVICES & 101.3 & 0.0002 & 0.01 & 15.3 \\
\hline PUBLIC ADMIN AND DEFENCE & 100.5 & 1.253 & 0.92 & 124.3 \\
\hline EDUCATION & 94.9 & 0.248 & 0.29 & 77.8 \\
\hline HEALTH AND SOCIAL WORK & 94.6 & 0.002 & 0.02 & 83.3 \\
\hline CONSTRUCTION & 94.2 & 1.041 & 0.60 & 161.1 \\
\hline Real estate activities & 93.4 & 11.352 & 0.97 & 1078.7 \\
\hline Renting of m\&eq and other business act. & 92.5 & 1.914 & 1.40 & 129.8 \\
\hline MINING AND QUARRYING & 92.3 & 0.065 & 0.13 & 844.7 \\
\hline OTHER COMMUNITY, SOC SERV & 91.2 & 1.863 & 1.60 & 107.5 \\
\hline HOTELS AND RESTAURANTS & 90.4 & 0.566 & 0.65 & 82.1 \\
\hline Average & 120.8 & 4.358 & 1.00 & 408.4 \\
\hline Correlation with MFP & 1 & 0.0024 & 0.0019 & 0.0027 \\
\hline
\end{tabular}




\section{Table 3: Panel unit root tests}

\begin{tabular}{|c|c|c|c|c|c|c|c|c|}
\hline & \multicolumn{4}{|c|}{ btexp } & \multicolumn{4}{|c|}{$m f p$} \\
\hline & \multicolumn{2}{|c|}{ CIPS $*(1)$} & \multicolumn{2}{|c|}{$\operatorname{IPS}^{(2)}$} & \multicolumn{2}{|c|}{ CIPS $*(1)$} & \multicolumn{2}{|c|}{$\operatorname{IPS}^{(2)}$} \\
\hline & Level, c,t & $1^{\text {st }}$ diff, c & Level, c,t & $1^{\text {st }}$ diff, c & Level, c,t & $1^{\text {st }}$ diff, c & Level, c,t & $1^{\text {st }}$ diff, c \\
\hline Electrical and optical equipment & $-2.777 *$ & $-2.469 * *$ & 2.858 & $-3.597 * *$ & -2.307 & $-2.784 * *$ & -0.660 & $-4.591 * *$ \\
\hline Transport equipment & -1.193 & -2.068 & -1.555 & $-9.026 * *$ & -0.918 & $-3.228 * *$ & 0.063 & $-8.472 * *$ \\
\hline Chemicals and chemical products & $-3.512 * *$ & $-2.760 * *$ & 1.833 & $-12.200 * *$ & -1.564 & $-2.601 * *$ & -0.259 & $-10.660 * *$ \\
\hline Machinery, nec & -2.000 & $-2.835 * *$ & 1.381 & $-10.411 * *$ & -2.434 & $-2.270 *$ & 0.980 & $-8.626 * *$ \\
\hline Rubber and plastics & $-3.294 * *$ & $-3.009 * *$ & 1.279 & $-6.110 * *$ & -2.717 & -2.037 & 1.504 & $-6.132 * *$ \\
\hline Manufacturing nec; recycling & -2.249 & $-2.764 * *$ & 0.250 & $-9.247 * *$ & -2.077 & $-3.099 * *$ & -0.513 & $-9.143 * *$ \\
\hline Other non-metallic mineral & -2.010 & $-2.302 * *$ & $-2.826 * *$ & $-11.066 * *$ & $-2.763^{*}$ & $-2.253 *$ & 0.690 & $-5.247 * *$ \\
\hline $\begin{array}{l}\text { Pulp, paper, paper, printing and } \\
\text { publishing }\end{array}$ & $-3.232 * *$ & $-3.273 * *$ & 1.836 & $-14.870 * *$ & $-3.125 * *$ & $-3.215^{* *}$ & -0.515 & $-9.265 * *$ \\
\hline Basic metals and fabricated metal & $-2.965 * *$ & $-2.655 * *$ & 1.583 & $-8.134 * *$ & -1.298 & $-2.426 * *$ & -0.284 & $-8.775 * *$ \\
\hline $\begin{array}{l}\text { Textiles, textile, leather and } \\
\text { footwear }\end{array}$ & $-3.070 * *$ & $-3.032 * *$ & 0.110 & $-5.127 * *$ & -2.566 & $-3.221 * *$ & 0.170 & $-8.249 * *$ \\
\hline $\begin{array}{l}\text { Coke, refined petroleum and } \\
\text { nuclear fuel }\end{array}$ & $-3.134 * *$ & $-2.703 * *$ & -0.615 & $-5.834 * *$ & $-2.744 *$ & $-2.282 *$ & 0.560 & $-7.257 * *$ \\
\hline Food, beverages and tobacco & -2.507 & $-2.960 * *$ & 1.955 & $-24.806 * *$ & $-2.969 * *$ & $-2.723 * *$ & -1.480 & $-8.064 * *$ \\
\hline Wood and of wood and cork & -1.753 & -1.873 & 2.858 & $-4.311 * *$ & $-3.374 * *$ & $-2.748 * *$ & -0.177 & $-9.350 * *$ \\
\hline Electricity, gas and water supply & -2.495 & $-3.100 * *$ & -1.378 & $-8.359 * *$ & -2.704 & $-3.087 * *$ & 0.222 & $-5.923 * *$ \\
\hline Construction & -1.840 & $-2.286^{*}$ & 1.027 & $-6.538 * *$ & -2.488 & $-3.025 * *$ & 0.171 & $-6.067 * *$ \\
\hline $\begin{array}{l}\text { Agriculture, hunting, forestry and } \\
\text { fish }\end{array}$ & -1.753 & $-2.950 * *$ & 0.663 & $-5.213 * *$ & -2.196 & $-3.658 * *$ & 0.226 & $-9.914 * *$ \\
\hline $\begin{array}{l}\text { Wholesale trade and commission } \\
\text { trade }\end{array}$ & -2.262 & $-3.394 * *$ & -0.532 & $-14.609 * *$ & -2.316 & $-2.205 *$ & -0.611 & $-7.767 * *$ \\
\hline $\begin{array}{l}\text { Retail trade, except of motor } \\
\text { vehicles }\end{array}$ & $-2.906 * *$ & $-3.330 * *$ & -0.489 & $-9.978 * *$ & -2.193 & $-3.231 * *$ & -0.850 & $-9.312 * *$ \\
\hline Hotels and restaurants & $-3.058 * *$ & $-2.891 * *$ & 2.158 & $-7.959 * *$ & $-2.791 *$ & $-2.587 * *$ & -0.771 & $-6.963 * *$ \\
\hline Post and telecommunications & -1.668 & $-2.926 * *$ & -1.116 & $-6.357 * *$ & -2.668 & $-2.914 * *$ & -0.511 & $-5.807 * *$ \\
\hline Real estate activities & -2.161 & -2.005 & 0.905 & $-10.920 * *$ & $-3.308 * *$ & $-3.387 * *$ & 1.237 & $-5.813 * *$ \\
\hline
\end{tabular}




\begin{tabular}{|c|c|c|c|c|c|c|c|c|}
\hline Public admin and defence & $-3.183 * *$ & $-2.324 * *$ & 1.444 & $-9.400 * *$ & -1.648 & $-2.279 * *$ & -0.276 & $-7.201 * *$ \\
\hline Education & $-3.259 * *$ & $-3.367 * *$ & 2.809 & $-9.895 * *$ & $-3.005 * *$ & $-2.576 * *$ & -1.506 & $-9.865 * *$ \\
\hline Health and social work & -2.066 & -2.001 & $-2.724 * *$ & $-17.557 * *$ & $-3.664 * *$ & $-2.726 * *$ & -0.818 & $-8.387 * *$ \\
\hline Mining and quarrying & -0.817 & $-2.546^{* *}$ & -2.395 & $-17.996 * *$ & -2.627 & $-2.858 * *$ & -0.007 & $-8.998 * *$ \\
\hline Transport and storage & $-3.403 * *$ & $-3.393 * *$ & 1.072 & $-12.702 * *$ & $-3.345 * *$ & $-2.500 * *$ & 0.192 & $-7.808 * *$ \\
\hline Financial intermediation & -1.696 & $-2.702 * *$ & -1.106 & $-6.068 * *$ & -1.803 & $-2.467 * *$ & 0.116 & $-6.462 * *$ \\
\hline $\begin{array}{l}\text { Renting of m\&eq and other } \\
\text { business activities }\end{array}$ & -2.071 & $-2.821 * *$ & $-2.727 * *$ & $-9.435 * *$ & $-3.153 * *$ & $-2.754 * *$ & 0.487 & $-9.915 * *$ \\
\hline Other community, social services & $-3.471 * *$ & $-3.572 * *$ & 0.909 & $-9.523 * *$ & $-2.726^{*}$ & $-2.443 * *$ & -0.559 & $-7.263 * *$ \\
\hline $\begin{array}{l}\text { Private households with employed } \\
\text { person }\end{array}$ & $-3.325 * *$ & $-2.651 * *$ & $-2.826^{* *}$ & 1.602 & -1.63 & $-2.486^{* *}$ & 0.690 & $-4.897 * *$ \\
\hline
\end{tabular}

(1) ** Rejects at $5 \%$ level. * Rejects at $10 \%$ level. All tests are one-sided tests, thus values of the test statistic to the left tail of the critical values are evidence for rejection of the null of a unit root. Exact $5 \%$ and $10 \%$ critical values for the CIPS* tests are with trend and intercept -2.89 and -2.73 respectively (T=10 and $\mathrm{N}=20$ ), and with intercept only -2.29 and $-2.15(\mathrm{~T}=10, \mathrm{~N}=20)$, (obtained from Tables IIb-IIc in Pesaran (2007)). For this test, there is no unit root if the test statistic is less than the critical value.

(2) All tests statistics are asymptotically distributed as $\mathrm{N}(0,1)$. * Rejects at $5 \%$ level. * Rejects at $10 \%$ level. All tests are one-sided tests, thus values of the test statistic in the left tail of the standard normal distribution are evidence for rejection of the null of a unit root. Exact critical values for the IPS tests are -1.89 (5\%) and -1.80 (10\%) without trend and $-2.56(5 \%)$ and $-2.47(10 \%)$ with trend (obtained from IPS (2003) Table 2 with T $=10$ and $\mathrm{N}=20$ ). 
Table 4: Panel unit root tests: Summary of Results

\begin{tabular}{lcccc}
\hline & \multicolumn{2}{c}{ btexp } & \multicolumn{2}{c}{$m f p$} \\
\cline { 2 - 5 } & CIPS*(1) & IPS ${ }^{(2)}$ & CIPS*(1) & IPS $(2)$ \\
\hline Electrical and optical equipment & $\mathrm{I}(0)$ & $\mathrm{I}(1)$ & $\mathrm{I}(1)$ & $\mathrm{I}(1)$ \\
\hline Transport equipment & $\mathrm{I}(1)$ & $\mathrm{I}(1)$ & $\mathrm{I}(1)$ & $\mathrm{I}(1)$ \\
\hline Chemicals and chemical products & $\mathrm{I}(0)$ & $\mathrm{I}(1)$ & $\mathrm{I}(1)$ & $\mathrm{I}(1)$ \\
\hline Machinery, nec & $\mathrm{I}(1)$ & $\mathrm{I}(1)$ & $\mathrm{I}(1)$ & $\mathrm{I}(1)$ \\
\hline Rubber and plastics & $\mathrm{I}(0)$ & $\mathrm{I}(1)$ & $\mathrm{I}(1)$ & $\mathrm{I}(1)$ \\
\hline Manufacturing nec; recycling & $\mathrm{I}(1)$ & $\mathrm{I}(1)$ & $\mathrm{I}(1)$ & $\mathrm{I}(1)$ \\
\hline Other non-metallic mineral & $\mathrm{I}(1)$ & $\mathrm{I}(0)$ & $\mathrm{I}(0)$ & $\mathrm{I}(1)$ \\
\hline Pulp, paper, printing and publishing & $\mathrm{I}(0)$ & $\mathrm{I}(1)$ & $\mathrm{I}(0)$ & $\mathrm{I}(1)$ \\
\hline Basic metals and fabricated metal & $\mathrm{I}(0)$ & $\mathrm{I}(1)$ & $\mathrm{I}(1)$ & $\mathrm{I}(1)$ \\
\hline Textiles, leather and footwear & $\mathrm{I}(0)$ & $\mathrm{I}(1)$ & $\mathrm{I}(1)$ & $\mathrm{I}(1)$ \\
\hline Coke, refined petroleum and nuclear fuel & $\mathrm{I}(0)$ & $\mathrm{I}(1)$ & $\mathrm{I}(0)$ & $\mathrm{I}(1)$ \\
\hline Food, beverages and tobacco & $\mathrm{I}(1)$ & $\mathrm{I}(1)$ & $\mathrm{I}(0)$ & $\mathrm{I}(1)$ \\
\hline Wood and of wood and cork & $\mathrm{I}(1)$ & $\mathrm{I}(1)$ & $\mathrm{I}(0)$ & $\mathrm{I}(1)$ \\
\hline Electricity, gas and water supply & $\mathrm{I}(1)$ & $\mathrm{I}(1)$ & $\mathrm{I}(1)$ & $\mathrm{I}(1)$ \\
\hline Construction & $\mathrm{I}(1)$ & $\mathrm{I}(1)$ & $\mathrm{I}(1)$ & $\mathrm{I}(1)$ \\
\hline Agriculture, hunting, forestry and fish & $\mathrm{I}(1)$ & $\mathrm{I}(1)$ & $\mathrm{I}(1)$ & $\mathrm{I}(1)$ \\
\hline Wholesale trade and commission trade & $\mathrm{I}(1)$ & $\mathrm{I}(1)$ & $\mathrm{I}(1)$ & $\mathrm{I}(1)$ \\
\hline Retail trade, except of motor vehicles & $\mathrm{I}(0)$ & $\mathrm{I}(1)$ & $\mathrm{I}(1)$ & $\mathrm{I}(1)$ \\
\hline Hotels and restaurants & $\mathrm{I}(0)$ & $\mathrm{I}(1)$ & $\mathrm{I}(0)$ & $\mathrm{I}(1)$ \\
\hline Post and telecommunications & $\mathrm{I}(1)$ & $\mathrm{I}(1)$ & $\mathrm{I}(1)$ & $\mathrm{I}(1)$ \\
\hline Real estate activities & $\mathrm{I}(1)$ & $\mathrm{I}(1)$ & $\mathrm{I}(0)$ & $\mathrm{I}(1)$ \\
\hline Public admin and defence & $\mathrm{I}(0)$ & $\mathrm{I}(1)$ & $\mathrm{I}(1)$ & $\mathrm{I}(1)$ \\
\hline Education & $\mathrm{I}(0)$ & $\mathrm{I}(1)$ & $\mathrm{I}(0)$ & $\mathrm{I}(1)$ \\
\hline Health and social work & $\mathrm{I}(1)$ & $\mathrm{I}(0)$ & $\mathrm{I}(0)$ & $\mathrm{I}(1)$ \\
\hline Mining and quarrying & $\mathrm{I}(1)$ & $\mathrm{I}(1)$ & $\mathrm{I}(1)$ & $\mathrm{I}(1)$ \\
\hline Transport and storage & $\mathrm{I}(0)$ & $\mathrm{I}(1)$ & $\mathrm{I}(0)$ & $\mathrm{I}(1)$ \\
\hline Financial intermediation & $\mathrm{I}(1)$ & $\mathrm{I}(1)$ & $\mathrm{I}(1)$ & $\mathrm{I}(1)$ \\
\hline Renting of m\&eq and other business & $\mathrm{I}(1)$ & $\mathrm{I}(0)$ & $\mathrm{I}(0)$ & $\mathrm{I}(1)$ \\
activities & & & & \\
\hline Other community, social services & $\mathrm{I}(0)$ & $\mathrm{I}(1)$ & $\mathrm{I}(0)$ & $\mathrm{I}(1)$ \\
\hline Private households with employed person & $\mathrm{I}(0)$ & $\mathrm{I}(0)$ & $\mathrm{I}(1)$ & $\mathrm{I}(1)$ \\
\hline ind & & concl & \\
\hline
\end{tabular}

(1) $\mathrm{I}(0)$ indicates that the null of a unit root was rejected at $10 \%$ significance level or less. 
Table 5: Panel Cointegration Tests: Group-mean ADF Statistic

\begin{tabular}{|c|c|}
\hline Independent variable & btexp \\
\hline Dependent Variable & $m f p$ \\
\hline Electrical and optical equipment & $-5.987 * *$ \\
\hline Transport equipment & -1.291 \\
\hline Chemicals and chemical products & $-6.737 * *$ \\
\hline Machinery, nec & $-6.302 * *$ \\
\hline Rubber and plastics & $-5.292 * *$ \\
\hline Manufacturing nec; recycling & $-3.276^{* *}$ \\
\hline Other non-metallic mineral & $-4.352 * *$ \\
\hline Pulp, paper, printing and publishing & $-7.798 * *$ \\
\hline Basic metals and fabricated metal & $-4.169 * *$ \\
\hline Textiles, leather and footwear & $-5.420 * *$ \\
\hline Coke, refined petroleum and nuclear fuel & $-6.718 * *$ \\
\hline Food, beverages and tobacco & $-12.761 * *$ \\
\hline Wood and of wood and cork & $-2.219^{*}$ \\
\hline Electricity, gas and water supply & $-3.793 * *$ \\
\hline Construction & $-5.194 * *$ \\
\hline Agriculture, hunting, forestry and fish & -4.052 * \\
\hline Wholesale trade and commission trade & $-5.868 * *$ \\
\hline Retail trade, except of motor vehicles & $-1.677^{*}$ \\
\hline Hotels and restaurants & $-2.701 * *$ \\
\hline Post and telecommunications & $-4.005 * *$ \\
\hline Real estate activities & $-6.273 * *$ \\
\hline Public admin and defence & $-3.756 * *$ \\
\hline Education & $-5.743 * *$ \\
\hline Health and social work & $-9.709 * *$ \\
\hline Mining and quarrying & $-8.891 * *$ \\
\hline Transport and storage & $-7.528 * *$ \\
\hline Financial intermediation & $-7.620 * *$ \\
\hline $\begin{array}{l}\text { Renting of m\&eq and other business } \\
\text { activities }\end{array}$ & $-2.293 *$ \\
\hline Other community, social and services & $-4.121 * *$ \\
\hline Private households with employed person & $-2.252 *$ \\
\hline
\end{tabular}

Notes:

(1) All tests statistics are asymptotically distributed as $\mathrm{N}(0,1)$. All tests are one-sided tests: reject the null of no cointegration if the test statistic value is less than the negative of the normal critical value. $*$ and $* *$ indicate rejection of the null of no cointegration at the $5 \%$ and $1 \%$ respectively.

(2) An intercept and a trend were included in the cointegrating regression. 
Table 6: Panel short-run causality tests (p-values) ${ }^{(1)}$

\begin{tabular}{|c|c|c|c|}
\hline & Levels & First Differences $^{(2)}$ & Joint Test \\
\hline \multirow{2}{*}{$\begin{array}{l}\text { Causality from } \\
\text { To }\end{array}$} & btexp & btexp & btexp \\
\hline & $m f p$ & $m f p$ & $m f p$ \\
\hline Electrical and optical equipment & 0.006 & 0.479 & 0.039 \\
\hline Transport equipment & 0.002 & 0.059 & 0.000 \\
\hline Chemicals and chemical products & 0.537 & 0.987 & 0.110 \\
\hline Machinery, nec & 0.001 & 0.316 & 0.218 \\
\hline Rubber and plastics & 0.003 & 0.592 & 0.002 \\
\hline Manufacturing nec; recycling & 0.002 & 0.717 & 0.003 \\
\hline Other non-metallic mineral & 0.013 & 0.558 & 0.095 \\
\hline Pulp, paper, printing and publishing & 0.000 & 0.038 & 0.000 \\
\hline Basic metals and fabricated metal & 0.324 & 0.922 & 0.002 \\
\hline Textiles, leather and footwear & 0.158 & 0.705 & 0.076 \\
\hline $\begin{array}{l}\text { Coke, refined petroleum and nuclear } \\
\text { fuel }\end{array}$ & 0.778 & 0.889 & 0.002 \\
\hline Food, beverages and tobacco & 0.679 & 0.740 & 0.006 \\
\hline Wood and of wood and cork & 0.863 & 0.747 & 0.092 \\
\hline Electricity, gas and water supply & 0.077 & 0.573 & 0.181 \\
\hline Construction & 0.135 & 0.566 & 0.000 \\
\hline Agriculture, hunting, forestry and fish & 0.911 & 0.852 & 0.063 \\
\hline Wholesale trade and commission trade & 0.055 & 0.216 & 0.000 \\
\hline Retail trade, except of motor vehicles & 0.004 & 0.670 & 0.000 \\
\hline Hotels and restaurants & 0.087 & 0.109 & 0.000 \\
\hline Post and telecommunications & 0.012 & 0.876 & 0.006 \\
\hline Real estate activities & 0.529 & 0.922 & 0.040 \\
\hline Public admin and defence & 0.121 & 0.965 & 0.012 \\
\hline Education & 0.747 & 0.771 & 0.001 \\
\hline Health and social work & 0.809 & 0.531 & 0.389 \\
\hline Mining and quarrying & 0.006 & 0.962 & 0.017 \\
\hline Transport and storage & 0.000 & 0.951 & 0.030 \\
\hline Financial intermediation & 0.341 & 0.551 & 0.258 \\
\hline $\begin{array}{l}\text { Renting of m\&eq and other business } \\
\text { acti }\end{array}$ & 0.297 & 0.820 & 0.003 \\
\hline Other community, social services & 0.997 & 0.979 & 0.002 \\
\hline $\begin{array}{l}\text { Private households with employed } \\
\text { person }\end{array}$ & 0.106 & 0.597 & 0.245 \\
\hline
\end{tabular}

(1) For all tests one lag was used. All tests statistics are asymptotically distributed as $\mathrm{N}(0,1)$. The $\mathrm{Z}$ test is a two-sided test. A p-value below 0.05 indicates rejection of the null of homogeneous non causality at $5 \%$ level.

(2) Only 15 countries included due to missing observations for Belgium and Japan. 
Table 7: Summary of panel short-run causality tests

\begin{tabular}{|c|c|c|c|}
\hline & Levels & First Differences & Joint Test \\
\hline \multirow{2}{*}{$\begin{array}{l}\text { Causality from } \\
\text { To }\end{array}$} & btexp & btexp & btexp \\
\hline & $m f p$ & $m f p$ & $m f p$ \\
\hline Electrical and optical equipment & Yes & No & Yes \\
\hline Transport equipment & Yes & Yes & Yes \\
\hline Chemicals and chemical products & No & No & No \\
\hline Machinery, nec & Yes & No & No \\
\hline Rubber and plastics & Yes & No & Yes \\
\hline Manufacturing nec; recycling & Yes & No & Yes \\
\hline Other non-metallic mineral & Yes & No & Yes \\
\hline $\begin{array}{l}\text { Pulp, paper, printing and } \\
\text { publishing }\end{array}$ & Yes & Yes & Yes \\
\hline Basic metals and fabricated metal & No & No & Yes \\
\hline Textiles, leather and footwear & No & No & Yes \\
\hline $\begin{array}{l}\text { Coke, refined petroleum and } \\
\text { nuclear fuel }\end{array}$ & No & No & Yes \\
\hline Food, beverages and tobacco & No & No & Yes \\
\hline Wood and of wood and cork & No & No & Yes \\
\hline Electricity, gas and water supply & Yes & No & No \\
\hline Construction & No & No & Yes \\
\hline $\begin{array}{l}\text { Agriculture, hunting, forestry and } \\
\text { fish }\end{array}$ & No & No & Yes \\
\hline $\begin{array}{l}\text { Wholesale trade and commission } \\
\text { trade }\end{array}$ & Yes & No & Yes \\
\hline $\begin{array}{l}\text { Retail trade, except of motor } \\
\text { vehicles }\end{array}$ & No & No & Yes \\
\hline Hotels and restaurants & Yes & No & Yes \\
\hline Post and telecommunications & Yes & No & Yes \\
\hline Real estate activities & No & No & Yes \\
\hline Public admin and defence & No & No & Yes \\
\hline Education & No & No & Yes \\
\hline Health and social work & No & No & No \\
\hline Mining and quarrying & Yes & No & Yes \\
\hline Transport and storage & Yes & No & Yes \\
\hline Financial intermediation & No & No & No \\
\hline $\begin{array}{l}\text { Renting of m\&eq and other } \\
\text { business activities }\end{array}$ & No & No & Yes \\
\hline Other community, social services & No & No & Yes \\
\hline $\begin{array}{l}\text { Private households with } \\
\text { employed person }\end{array}$ & No & No & No \\
\hline
\end{tabular}

(1) Yes indicates that the null of no causality was rejected at $10 \%$ significance level or less. 
Table 8: Panel long-run causality tests (p-values) ${ }^{(1)}$

Causality from

To btexp

mfp

$\begin{array}{cc}\text { Long-run } & \text { Long-run Causality } \\ \text { Lambda-Pearson }\end{array}$

mean $t$ test

\begin{tabular}{|c|c|c|}
\hline & mean $t$ test & test \\
\hline Electrical and optical equipment & 0.17 & 0.00 \\
\hline Transport equipment & 0.20 & 0.09 \\
\hline $\begin{array}{l}\text { Chemicals and chemical } \\
\text { products }\end{array}$ & 0.04 & 0.00 \\
\hline Machinery, nec & 0.06 & 0.00 \\
\hline Rubber and plastics & 0.17 & 0.00 \\
\hline Manufacturing nec; recycling & 0.02 & 0.00 \\
\hline Other non-metallic mineral & 0.03 & 0.00 \\
\hline $\begin{array}{l}\text { Pulp, paper, printing and } \\
\text { publishing }\end{array}$ & 0.24 & 0.00 \\
\hline $\begin{array}{l}\text { Basic metals and fabricated } \\
\text { metal }\end{array}$ & 0.06 & 0.00 \\
\hline Textiles, leather and footwear & 0.06 & 0.00 \\
\hline $\begin{array}{l}\text { Coke, refined petroleum and } \\
\text { nuclear fuel }\end{array}$ & 0.19 & 0.01 \\
\hline Food, beverages and tobacco & 0.28 & 0.00 \\
\hline Wood and of wood and cork & 0.17 & 0.00 \\
\hline $\begin{array}{l}\text { Electricity, gas and water } \\
\text { supply }\end{array}$ & 0.17 & 0.00 \\
\hline Construction & 0.02 & 0.00 \\
\hline $\begin{array}{l}\text { Agriculture, hunting, forestry } \\
\text { and fish }\end{array}$ & 0.20 & 0.02 \\
\hline $\begin{array}{l}\text { Wholesale trade and } \\
\text { commission trade }\end{array}$ & 0.11 & 0.01 \\
\hline $\begin{array}{l}\text { Retail trade, except of motor } \\
\text { vehicles }\end{array}$ & 0.03 & 0.00 \\
\hline Hotels and restaurants & 0.04 & 0.00 \\
\hline Post and telecommunications & 0.06 & 0.00 \\
\hline Real estate activities & 0.06 & 0.00 \\
\hline Public admin and defence & 0.09 & 0.00 \\
\hline Education & 0.45 & 0.05 \\
\hline Health and social work & 0.15 & 0.01 \\
\hline Mining and quarrying & 0.03 & 0.00 \\
\hline Transport and storage & 0.04 & 0.00 \\
\hline Financial intermediation & 0.11 & 0.00 \\
\hline $\begin{array}{l}\text { Renting of m\&eq and other } \\
\text { business activities }\end{array}$ & 0.22 & 0.06 \\
\hline $\begin{array}{l}\text { Other community, social } \\
\text { services }\end{array}$ & 0.10 & 0.00 \\
\hline $\begin{array}{l}\text { Private households with } \\
\text { employed person }\end{array}$ & 0.02 & 0.00 \\
\hline
\end{tabular}

Notes:

(1) For all tests one lag was used. 
Table 9: Panel DOLS estimates for elasticities of $m f p$ with respect to btexp

\begin{tabular}{|c|c|}
\hline Electrical and optical equipment & 0.61 \\
\hline Transport equipment & 0.20 \\
\hline Chemicals and chemical products & 0.54 \\
\hline Machinery, nec & 0.31 \\
\hline Rubber and plastics & 0.18 \\
\hline Manufacturing nec; recycling & 0.20 \\
\hline Other non-metallic mineral & 0.43 \\
\hline Pulp, paper, printing and publishing & 0.14 \\
\hline Basic metals and fabricated metal & 0.16 \\
\hline Textiles, leather and footwear & 0.19 \\
\hline Coke, refined petroleum and nuclear fuel & 0.11 \\
\hline Food, beverages and tobacco & 0.04 \\
\hline Wood and of wood and cork & 0.07 \\
\hline Electricity, gas and water supply & 0.05 \\
\hline Construction & -0.10 \\
\hline Agriculture, hunting, forestry and fish & 0.45 \\
\hline Wholesale trade and commission trade & 0.20 \\
\hline Retail trade, except of motor vehicles & 0.20 \\
\hline Hotels and restaurants & -0.02 \\
\hline Post and telecommunications & 0.39 \\
\hline Real estate activities & -0.19 \\
\hline Public admin and defence & 0.01 \\
\hline Education & 0.01 \\
\hline Health and social work & 0.03 \\
\hline Mining and quarrying & -0.10 \\
\hline Transport and storage & 0.07 \\
\hline Financial intermediation & 0.49 \\
\hline Renting of m\&eq and other business activities & 0.13 \\
\hline Other community, social services & -0.07 \\
\hline Private households with employed person & 0.07 \\
\hline
\end{tabular}

